\title{
Pengaruh Kosentrasi dan Frekuensi Pemberian Pupuk Hayati Bio-EXTRIM Terhadap Pertumbuhan dan Hasil Tanaman Wortel (Daucus carota L.) dalam Pot di Dataran Rendah
}

\section{The Effect of Concentration and Frequency of Bio-EXTRIM Applications on Growth and Yield of Carrot (Daucus carota L.) Plants Cultivated on Pots in Lowland}

\author{
Riana Amalia, Aluh Nikmatullah*, Karwati Zawani \\ Program Studi Agroekoteknologi Fakultas Pertanian, Universitas Mataram \\ Jl. Majapahit 62 Mataram 83125, Telp.(0370) 646506 INDONESIA \\ *corresponding author,email: aluh_nikmatullah@unram.ac.id
}

Manuscript received: 11-11-2019. Accepted: 26-12-2019

\begin{abstract}
ABSTRAK
Penelitian ini bertujun untuk mengetahui pengaruh konsentrasi dan frekuensi pemberian pupuk hayati Bio-EXTRIM serta interaksinya terhadap pertumbuhan dan hasil tanaman wortel (Daucus carota L.) di dalam pot di dataran rendah. Penelitian ini dilaksanakan di areal persawahan di Dusun Siren, Desa Rumbuk Timur, Kecamatan Lombok Timur pada bulan Maret - Juni 2019 dengan Rancangan Acak Kelompok (RAK) faktorial, dua faktor. Faktor pertama konsentrasi pupuk hayati Bio-EXTRIM dan faktor kedua yaitu frekuensi pemberian pupuk hayati Bio-EXTRIM yang masing-masing terdiri dari 3 taraf sehingga didapatkan 9 interaksi perlakuan yaitu konsentrasi $0,25 \%$ dengan frekuensi 4 kali , konsentrasi $0,25 \%$ dengan frekuensi 5 kali, konsentrasi 0,25\% dengan frekuensi 6 kali, konsentrasi 0,5\% dengan frekuensi 4 kali, konsentrasi $0,5 \%$ dengan frekuensi 5 kali, konsentrasi $0,5 \%$ dengan frekuensi 6 kali, konsentrasi $1 \%$ dengan frekuensi 4 kali, konsentrasi $1 \%$ dengan frekuensi 5 kali, konsentrasi 1\% dengan frekuensi 6 kali, dengan 5 kali ulangan sehingga terdapat 45 unit percobaan. Hasil penelitian menunjukkan bahwa konsentrasi pupuk hayati Bio-EXTRIM berpengaruh terhadap laju pertumbuhan panjang tangkai daun tanaman wortel. Konsentrasi yang menghasilkan laju pertumbuhan panjang tangkai daun tertinggi adalah $0,25 \%$. Frekuensi pemberian pupuk hayati Bio-EXTRIM berpengaruh terhadap berat biomassa kering daun, diameter tengah umbi dan kadar gula umbi. Berat biomassa kering daun dan diameter tengah umbi tertinggi diperoleh pada tanaman wortel yang diberikan pupuk hayati Bio-EXTRIM sebanyak 4 kali, sedangkan umbi paling manis diperoleh pada tanaman wortel yang diberikan pupuk hayati Bio-EXTRIM sebanyak 6 kali. Meskipun demikian, tidak terdapat interaksi antara konsentasi dan frekuensi pemberian pupuk hayati Bio-EXTRIM terhadap pertumbuhan dan hasil tanaman wortel di dalam pot.
\end{abstract}

Kata kunci: organik; pekarangan; pupuk hayati; kawasan rumah pangan lestari 


\begin{abstract}
This study aimed to determine the effect of the concentration and frequency of Bio-EXTRIM biofertilizer applications and their interactions on the growth and yield of carrot (Daucus carota L.) plants cultivated using pots in the lowland. This research was conducted in the rice fields of Siren Hamlet, East Rumbuk Village, East Lombok sub-district, from March toJune 2019, and arranged according to the Randomized Block Design (RBD) factorial with two factors. The first factor was the concentration of Bio-EXTRIM and the second factor was the frequency of Bio-EXTRIM applications; each consisted of 3 levels and thus resulted in 9 interractio. The interraction were: concentration of $0.25 \%$ with 4 times application, concentration of $0.25 \%$ with 5 times application, concentration of $0.25 \%$ with 6 times application, concentration of $0.5 \%$ with 4 times application, concentration of $0.5 \%$ with 5 times application, concentration of $0.5 \%$ with 6 times application, concentration of $1 \%$ with 4 times application, concentration of $1 \%$ with 5 times application, and concentration of $1 \%$ with 6 times application. The results showes that the concentration of Bio-EXTRIM biofertilizer had significant effect on the rate of carrot leaf stalks growth, with concentration of $0.25 \%$ had the highest leaf stalk growth rate. The frequency of Bio-EXTRIM biofertilizer applications influenced the dry weight of leaf biomass, the middle diameter of the carrot root and the sugar content of the carrot root. The highest dry weight of leaf biomass and diameter of the tuber were obtained in carrot plants treated with BioEXTRIM biofertilizer for 4 times, while the sweetest tubers were obtained in carrot plants treated with Bio-EXTRIM biofertilizer for 6 times. However, there was no interaction between the concentration and frequency of Bio-EXTRIM biofertilizers in influencing the growth and yield of carrots grown in the pots in the lowlands.
\end{abstract}

Keyword: organic; backyards; biofertilizers; sustainable food home area

\title{
PENDAHULUAN
}

Pangan merupakan kebutuhan mendasar bagi manusia untuk melanjutan hidupnya. Dalam rangka mewujudkan pemenuhan kebutuhan pangan bagi seluruh masyarakat di suatu wilayah, maka ketersediaan pangan menjadi sasaran utama dalam kebijakan pemerintah di suatu negara (Yonifwisma, 2016). Oleh karena itu, peningkatan kebutuhan pangan Nasional menjadi salah satu program prioritas pemerintah Indonesia. Kecukupan pangan nasional tidak menjamin bahwa semua rumah tangga memperoleh pangan yang dibutuhkan. Sehingga salah satu fokus program ketahanan pangan adalah rumah tangga yaitu melalui pemberdayaan rumah tangga dan masyarakat agar mampu menolong dirinya sendiri dalam mewujudkan ketahanan pangan dan mengatasi masalah-masalah pangan yang dihadapi (Purwaningsih, 2008).

Pembangunan ketahanan pangan di Indonesia dilakukan melalui konsep Kawasan Rumah Pangan Lestari (KRPL). KRPL merupakan konsep pemberdayaan penduduk di suatu kawasan secara bersama-sama mengusahakan pekarangannya secara intensif guna untuk dimanfaatkan menjadi sumber pangan secara berkelanjutan (Wijayanti dkk, 2017). Oleh karena itu, lahan pekarangan merupakan salah satu sumber potensial penyediaan bahan pangan (Saptana, 2011). Pemanfaat lahan pekarangan untuk kegiatan budidayaakan dapat meningkatkan ketersediaan pangan keluarga (Nikmatullah, dkk. 2018).

Implementasi kegiatan KRPL di Indonesia dilakukan sejak tahun 2013 dan saat ini telah dilakukan 407 program KRPL di Nusa Tenggara Barat. Pola KRPL di NTB adalah KRPL tanaman saja, ternak dan ternak dan tanaman, ternak dan ikan (Nikmatullah, dkk. 2018). Salah satu tanaman yang potensial untuk dibudidayakan dalam KRPL tersebut adalah wortel (Daucus carota L.). 
Kandungan gizi wortel per $100 \mathrm{~g}$ adalah energi sebanyak $172 \mathrm{kj}$ atau $41 \mathrm{kkal}$, lemak sebesar 0,24 gram, lemak jenuh sebesar $0,037 \mathrm{~g}$, lemak tak jenuh ganda sebasar 0,117 g, lemak tak jenuh tunggal sebasar $0,014 \mathrm{~g}$, kolesterol sebesar $0 \mathrm{mg}$, proten sebesar $0,93 \mathrm{~g}$, karbohidrat sebesar 9,58 g, serat sebesar 2,8 g, gula sebesar 4,54 g, sodium $69 \mathrm{~g}$, kalium sebesar $320 \mathrm{mg}$ (Fatsecret Indonesia, 2018). Wortel termasuk dalam sayuran dengan kandungan beta karoten yang tinggi. Beta karoten merupakan salah satu jenis karotenoid provitamin A dan berperan sebagai antioksidan kuat yang sangat bermanfaat bagi proses metabolisme yang terjadi pada tubuh manusia. Kandungn rata-rata beta karoten pada wortel adalah 7,63 $\pm 0,33^{\circ} \mu \mathrm{g} / \mathrm{g}$ (Adelina, dkk. 2013).

Agar dapat tumbuh dengan baik, tanaman wortel (Daucus carota L.) menghendaki suhu optimal $18-21^{\circ}$, suhu udara tersebut di daerah tropis umumnya tercapai pada ketinggian $>500$ $-1.000 \mathrm{~m}$ di atas permukaan laut (dpl). Upaya pengembangan wortel di dataran rendah bersuhu $>28^{\circ} \mathrm{C}$ di Indonesia belum banyak dilakukan. Varietas wortel yang memiliki adaptasi terbaik adalah Varietas Cisarua, berdasarkan parameter daya kecambah benih, bobot umbi, tingkat serangan penyakit busuk daun dan tingkat kemanisan daging (Firmansyah, dkk. 2016). Selain itu, varietas lain yang dapat tumbuh dan beradaptasi di dataran rendah yaitu varietas Berastagi atau Gundaling. Namun, hasil dan mutu hasilnya masih rendah (Zawani, dkk. 2018).

Dibutuhkan suatu teknik budidaya yang sesuai untuk dapat menghasilkan umbi wortel bermutu dengan produksi yang tinggi di dataran rendah. Salah satunya adalah memberikan nutrisi berimbang dan perlakuan dengan pemberian hormon tumbuhan (fitohormon). Sebagai sayuran yang dikonsumsi dalam bentuk segar, budidaya wortel sebaiknya dilakukan secara organik. Salah satu upaya yang dapat dilakukan untuk meningkatkan hasil umbi wortel di dataran rendah adalah dengan memberikan pupuk hayati yang mengandung unsur hara, mikroorganisme dan fitohormon seperti yang terdapat pada pupuk hayati Bio-EXTRIM. BioEXTRIM mengandung C-organik, nitrogen, fosfor, kalium, kalsium, kelompok bakteri penambat N dari udara seperti Rhizobium sp., Azospirilium, Azetobacter sp.; kelompok bakteri pelarut fosfat; Pseudomonas sp dan Bacillus sp. Selain itu, BioEXTRIM juga mengandung fitohormon yaitu auksin, giberelin, sitokinin dan asam absisat (Aba) (Gunawan, 2018).

Efektiviatas pupuk hayati Bio-EXTRIM tergantung pada konsentrasi, frekuensi pemberian dan jenis tanaman yang diperlakukan. Pada tanaman kakao (Theobroma cacao L.) Sagala dkk. (2011) melaporkan konsentrasi optimum untuk meningkatkan pertumbuhannya adalah $10 \mathrm{ml} / \mathrm{L}$. Konsentrasi antara $5 \mathrm{~mL} / \mathrm{L}$ sampai $15 \mathrm{ml} / \mathrm{L}$ dilaporkan dapat meningkatkan bobot berangkasan basah dan bobot produksi tanaman selada (Noviana, 2018). Pada tanaman selada, pemberian Bio-EXTRIM dilakukan sebanyak 3 kali, sedangkan pada tanaman bunga kol frekuensi pemberian yang memberikan hasil panen (bobot bunga kol) terbaik adalah 4 kali dengan dosis 4 L/ha (Ningsih, 2017). Oleh karena itu, telah dilakukan satu penelitian yang bertujuan untuk untuk mengetahui pengaruh konsentrasi dan frekuensi pemberian pupuk hayati Bio-EXTRIM serta interaksi antaranya terhadap pertumbuhan dan hasil tanaman wortel (Daucus carota L.) di dalam pot di dataran rendah 


\section{MATERI DAN METODE}

Waktu, Lokasi dan Bahan Penelitian

Penelitian ini menggunakan metode ekperimental yang dilakukan mulai dari Bulan Maret - Juni 2019 di areal persawahan Dusun Siren, Desa Rumbuk Timur, Kecamatan Sakra, Kabupaten Lombok Timur. Benih yang digunakan adalah benih wortel varietas Gundaling Benih tersebut diperoleh dari BBI Kuta Gadung, Berastagi, Sumatra Utara.

\section{Perlakuan dan Desain Percobaan}

Penelitian ini menggunakan Rancangan Acak kelompok (RAK) Faktorial. Faktor pertama adalah konsentrasi pemberian pupuk hayati Bio-EXTRIM yang terdiri dari 3 taraf yaitu K1 $(0,25 \%)$. K2 $(0,5 \%)$ dan K3 $(1 \%)$ dan faktor kedua adalah frekuensi pemberian pupuk hayati Bio-EXTRIM yang terdiri dari 3 taraf yaitu F1 (4 kali pemberian) F2 (5 kali pemberian),F3 (6 kali pemberian), sehingga terbentuk 9 interaksi perlakuan yaitu k1f1, k1f2, $\mathrm{k} 1 \mathrm{f} 3, \mathrm{k} 2 \mathrm{f} 1, \mathrm{k} 2 \mathrm{f} 2$, k2f3, k3f1, k3f2, k3f3 dengan 5 ulangan sehingga terdapat 45 unit percobaan.

\section{Pelaksanaan Percobaan}

Penaman tanaman wortel pada penelitian ini adalah di dalam polybag menggunakan media tanam berupa campuran tanah topsoil yang telah diayak dan sekam dengan perbandingan 1:1 (v:v). Media yang telah dicampur kemudian dimasukkan ke dalam polybag ukuran 25 x 30 $\mathrm{cm}$. Media tanam dimasukkan ke dalam polibag sampai $25 \mathrm{~cm}$ (menyisakan $5 \mathrm{~cm}$ bagian atas polybag yang tidak terisi media tanam). Benih wortel ditanam dalam setiap polybag (3 benih per polibag), polibag disiram, dan dilakukan penjarangan pada umur 28 HST dengan cara menyisakan 1 bibit tanaman sehat yang berukuran seragam pada setiap polibag. Tanaman dipupuk dengan pupuk kandang ayam (dosis 20 ton/ha atau $114 \mathrm{~g}$ per polibag). Pemupukan dilakukan 2 kali selama pertumbuhan tanaman yaitu $1 / 2$ dosis diberikan ketika persiapan media tanam dan $1 / 2$ dosis diberikan ketika tanaman berumur 45 HST. Pengendaian hama dan penyakit tanaman dilakukan dengan meletakkan perangkap hama (yellow sticky trap) di sekitar areal percobaan, perlakuan dengan jamur Metarhizium anisopliae (pada umur 1, 5 dan 15 MST), dan perlakuan tanaman dengan jamur Beuveria basiana (pada umur 2, 4, 6, 8, 10 MST).

Pertumbuhan tanaman diamati dengan menghitung laju pertumbuhan jumlah daun, laju pertumbuhan tinggi tanaman, berat biomassa basah dan kering tanaman. Laju pertumbuhan jumlah daun dan laju pertumbuhan tinggi tanaman dihitung dengan analisa regresi linier dari fungsi jumlah daun atau tinggi tanaman per dua minggu. Berat biomassa segar tanaman baik daun maupun umbi ditimbang menggunakan timbangan digital, sedangkan berat biomassa kering daun maupun umbi diukur setelah biomassa tanaman dikeringkan dalam oven pada suhu $70^{\circ} \mathrm{C}$ sampai mencapai berat konstan dan ditimbang dengan timbangan digital.

Hasil dan mutu hasil tanaman wortel diamati setelah panen pada parameter panjang umbi, diameter umbi (diukur dengan jangka sorong), kekerasan umbi (diukur dengan penetrometer), kadar gula umbi (diukur dengan refraktometer), serta perbandingan berat antara korteks dengan stele pada umbi.

Sebelum penanaman, dilakukan analisa kimia pada media tanam dan pupuk kandang ayam yang digunakan untuk mengetahui kadar dan ketersediaan unsur hara pada media dan 
pupuk kandang ayam yang digunakan. Selama penelitian dilakukan pengamatan terhadap suhu dan kelembaban mingguan menggunakan thermohydrometer.

Data hasil penelitian ini dianalisis dengan Analysis of Varience (ANOVA) pada taraf kepercayaan 5\% dan data yang berbeda nyata diuji lanjut menggunakan uji Beda Nyata Jujur (BNJ) pada taraf nyata yang sama.

\section{HASIL DAN PEMBAHASAN}

Media tanam yang digunakan dalam penelitian ini adalah tanah top soil dan arang sekam yang memiliki perbandingan 1:1 (v:v), sedangkan pupuk kandang ayam yang diberikan pada tanaman wortel dalam pot di dataran rendah ini menggunakan dosis 20 ton per Ha atau setara dengan 114 gram per pot. Ketersediann unsur hara pada media tanam dan pupuk kandang ayam ditunjukan pada Tabel 1.

Tabel 1. Ketersediaan Unsur Hara Media Tanam dan Pupuk Kandang Ayam

\begin{tabular}{|c|c|c|c|}
\hline Sampel & Parameter Analisa & Nilai & Kategori \\
\hline \multirow[t]{5}{*}{ Media tanam } & C-organik (\%) & 2,24 & Sedang $^{*}$ \\
\hline & N-Total $(\%)$ & 0,09 & Sangat Rendah ${ }^{*}$ \\
\hline & P-Tersedia (ppm) & 564,71 & Sangat Tinggi* \\
\hline & K-Tersedia (meq\%) & 2,94 & Sangat Tinggi* \\
\hline & $\mathrm{C} / \mathrm{N}(\%)$ & 2,67 & Sangat Rendah ${ }^{*}$ \\
\hline \multirow[t]{5}{*}{ Pupuk Kandang Ayam } & C-organik (\%) & 28,61 & Sangat Tinggi $^{*}$ \\
\hline & N-Total $(\%)$ & 0,98 & Sangat Tinggi* \\
\hline & P-Total $(\%)$ & 1,88 & Sangat Tinggi ${ }^{*}$ \\
\hline & K-Total $(\%)$ & 2,75 & SangatTinggi * \\
\hline & $\mathrm{C} / \mathrm{N}(\%)$ & 29,19 & Sangat Tinggi ${ }^{*}$ \\
\hline
\end{tabular}

Keterangan: Berdasarkan kriteria Balai Penelitian Tanah, Badan Penelitian dan Pengembangan Pertanian, Departemen Pertanian (Prijatna,2006).

Media tanam yang digunakan dalam penelitian ini memiliki kandungan unsur hara berupa C-Organik sebesar 2,24\% (sedang), N-Total sebesar 0,09\% (sangat rendah), P-Tersedia sebesar 564,71 ppm (sangat tinggi), K-Tersedia sebesar 2,94 meq\% (sangat tinggi) dan C/N sebesar 2,67\% (Sangat Rendah). Sementara unsur hara yang terdapat pada pupuk kandang ayam baik itu C-Organik, N-Total, P-Total, K-Total dan C/N dengan kadar yang sangat tinggi.

Hasil analisis sidik ragam pengaruh konsentrasi, frekuensi pemberian pupuk hayati BioEXTRIM dan interaksi antara keduanya terhadap pertumbuhan dan hasil tanaman wortel dalam pot di dataran rendah adalah konsentrasi dan frekuensi pemberian pupuk hayati BioEXTRIM, interaksi keduanya berpengaruh tidak nyata pada setiap parameter pertumbuhan dan hasil tanaman wortel dalam pot di dataran rendah, kecuali pada parameter laju pertumbuhan panjang tangkai daun, parameter biomassa kering daun, diameter umbi tengah dan kadar gula umbi.

Pengaruh konsentrasi dan frekuensi pemberian pupuk hayati Bio-EXTRIM, serta interaksi antara keduanya terhadap laju pertumbuhan jumlah daun, laju pertumbuhan panjang tangkai daun disajikan pada Tabel 2. 
Tabel 2. Laju Pertumbuhan Jumlah Daun Tanaman Wortel dalam Pot di Dataran Rendah

\begin{tabular}{|c|c|c|}
\hline Perlakuan & $\begin{array}{l}\text { Laju pertumbuhan Jumlah Daun } \\
(\mathrm{cm} / 2 \text { Minggu) }\end{array}$ & $\begin{array}{l}\text { Laju Pertumbuhan Panjang Tangkai Daun } \\
\text { (cm/2 minggu) }\end{array}$ \\
\hline $\mathrm{k} 1(0,25 \%)$ & 5,46 & $12,25 \mathrm{a}^{*}$ \\
\hline k2 $(0,5 \%)$ & 4,54 & $10,22 \mathrm{ab}^{*}$ \\
\hline k3 (1\%) & 4,75 & $7,03 b^{*}$ \\
\hline BNJ 5\% & - & 3,88 \\
\hline f1 (4 Kali) & 4,98 & 10,48 \\
\hline f2 (5 Kali) & 5,40 & 10,53 \\
\hline f3 (6 Kali) & 4,37 & 8,49 \\
\hline BNJ 5\% & - & - \\
\hline \multirow[t]{3}{*}{ k1 } & 5,34 & 12,97 \\
\hline & 7,22 & 11,35 \\
\hline & 3,83 & 12,43 \\
\hline \multirow[t]{3}{*}{ k2 } & 4,13 & 11,13 \\
\hline & 4,19 & 11,97 \\
\hline & 5,29 & 7,56 \\
\hline \multirow{3}{*}{$\begin{array}{l}\text { f1 } \\
\text { f2 } \\
\text { f3 }\end{array}$} & 5,46 & 7,35 \\
\hline & 4,80 & 8,28 \\
\hline & 3,99 & 5,48 \\
\hline
\end{tabular}

BNJ $5 \%$

Keterangan: Angka-angka dalam suatu kolom yang ditandai dengan hurup (superskrif) yang sama menunjukkan hasil yang berbeda nyata berdasarkan uji lanjut BNJ pada $\alpha=5 \%$, K: Konsentrasi, F: Frekuensi.

Pada Tabel 2. menunjukan perlakuan konsentrasi pemberian pupuk hayati BioEXTRIM berpengaruh tidak nyata pada parameter laju pertumbuhan jumlah daun dan berpengaruh nyata pada parameter laju pertumbuhan panjang tangkai daun, sedangkan perlakuan frekuensi dan interaksi antara konsentrasi dan frekuensi pemberian pupuk hayati Bio-EXTRIM berpengaruh tidak nyata pada parameter laju pertumbuhan jumlah daun dan laju pertumbuhan panjang tangkai daun.

Pemberian pupuk hayati Bio-EXTRIM dengan konsentrasi terendah $0,25 \%$ menghasilkan laju pertumbuhan panjang tangkai daun paling tinggi yaitu $12,25 \mathrm{~cm} / 2 \mathrm{minggu}$, sedangkan laju pertumbuhan panjang tangkai daun pada konsentrasi $0,5 \%$ dan $1 \%$, berturutturut sebesar 10,22 cm/2 minggu dan 7,03 cm/2 minggu. Berdasarkan hal tersebut, konsentrasi yang memiliki laju pertumbuhan panjang tangkai daun tertinggi adalah konsentrasi terendah yaitu $0,25 \%$. Noviana, dkk. (2018) menyatakan bahwa peningkatan konsentrasi Bio-EXTRIM belum tentu akan meningkatkan pertumbuhan tanaman. Hal ini diduga karena meningkatnya kompetisi antara mikroorganisme dengan bertambahnya populasi mikroorganisme. Menurut Kurniawan, dkk. (2013), semakin tinggi konsentrasi penambahan pupuk hayati, maka jumlah mikroorganisme di dalam media tanam semakin bertambah, namun apabila tidak diimbangi dengan peningkatan kadar bahan organik tanah akan menyebabkan semakin minimnya makanan bagi mikroorganisme. Hasil analisi kimia media tanam menunjukan kadar C-Organik tergolong rendah yaitu 2,24\%, sehingga bahan organik yang menjadi makanan bagi mikroorganisme tanah juga rendah. 
Tabel 3. Biomassa Kering Umbi,Biomassa Kering Daun Biomassa Kering Total Tanaman, Diameter Umbi Atas, Diameter Umbi Tengah, Diameter Umbi Ujung.

\begin{tabular}{|c|c|c|c|c|c|c|c|}
\hline \multicolumn{2}{|c|}{ Perlakuan } & $\begin{array}{r}\text { BKU } \\
(\mathrm{g})\end{array}$ & $\begin{array}{r}\text { BKD } \\
(\mathrm{g})\end{array}$ & $\begin{array}{r}\text { BKTT } \\
(\mathrm{g})\end{array}$ & DUA (cm) & DUT (cm) & $\begin{array}{c}\text { DUU } \\
(\mathrm{cm})\end{array}$ \\
\hline \multicolumn{2}{|c|}{$\mathrm{k} 1(0,25 \%)$} & 5,77 & 6,94 & 12,71 & 2,25 & 2,17 & 0,39 \\
\hline \multicolumn{2}{|c|}{ k2 $(0,5 \%)$} & 4,16 & 5,29 & 9,45 & 2,27 & 2,01 & 0,30 \\
\hline \multicolumn{2}{|c|}{ k3 (1\%) } & 4,34 & 6,10 & 10,44 & 2,13 & 1,99 & 0,29 \\
\hline \multicolumn{2}{|c|}{ BNJ 5\% } & - & - & - & - & - & \\
\hline \multicolumn{2}{|c|}{ f1 (4 Kali) } & 5,75 & 7,51a* & 13,25 & 2,47 & $2,21 a^{*}$ & 0,30 \\
\hline \multicolumn{2}{|c|}{ f2 (5 Kali) } & 4,21 & $5,01 b^{*}$ & 9,27 & 2,07 & $2,09 a b^{*}$ & 0,38 \\
\hline \multicolumn{2}{|c|}{ f3 (6 Kali) } & 4,31 & $5,76 \mathrm{ab}^{*}$ & 10,07 & 2,11 & $1.86 b^{*}$ & 0,28 \\
\hline \multicolumn{2}{|c|}{ BNJ 5\% } & - & 2,36 & - & - & 0,33 & - \\
\hline \multirow[t]{3}{*}{ k1 } & f1 & 7,40 & 8,30 & 15,66 & 2,80 & 2,40 & 0,38 \\
\hline & $\mathrm{f} 2$ & 5,10 & 6,36 & 11,50 & 2,06 & 2,36 & 0,48 \\
\hline & f3 & 4,80 & 6,16 & 10,96 & 1,89 & 1,74 & 0,30 \\
\hline \multirow[t]{3}{*}{$\mathrm{k} 2$} & f1 & 4,30 & 5,78 & 10,10 & 2,60 & 2,10 & 0,30 \\
\hline & $\mathrm{f} 2$ & 4,10 & 4,56 & 8.66 & 2,16 & 1,89 & 0,32 \\
\hline & $\mathrm{f} 3$ & 4,10 & 5,54 & 9,60 & 2,28 & 2,03 & 0,26 \\
\hline \multirow[t]{3}{*}{ k3 } & f1 & 5,60 & 8,44 & 14,00 & 2,25 & 2,12 & 0,22 \\
\hline & $\mathrm{f} 2$ & 3,40 & 4,28 & 7,66 & 1,98 & 2,03 & 0,35 \\
\hline & $\mathrm{f} 3$ & 4,10 & 5,58 & 9,66 & 2,17 & 1,80 & 0,29 \\
\hline
\end{tabular}

\begin{tabular}{lccccc}
\hline BNJ $5 \%$ & - & - & - & - & -
\end{tabular} hasil yang berbeda nyata berdasarkan uji lanjut BNJ pada $\alpha=5 \%$, K: Konsentrasi, F: Frekuensi, BKU: Biomassa Kering Umbi, BKD: Biomassa Kering Daun, dan BKTT: Biomassa Kering, DUA: Diameter Umbi Atas, DUT: Diameter Umbi Tengah; DUU: Diameter Umbi Ujung, Total Tanaman, BNJ: Beda Nyata Jujur.

Pemberian pupuk hayati Bio-EXTRIM dengan beberapa konsentrasi berpengaruh tidak nyata terhadap biomassa kering umbi,biomassa kering daun biomassa kering total tanaman, diameter umbi atas, diameter umbi tengah, diameter umbi ujung, sedangkan pemberian pupuk hayati Bio-EXTRIM dengan beberapa frekuensi berpengaruh nyata terhadap biomassa kering daun dan diameter umbi tengah (Tabel 3.).

Frekuensi pemberian pupuk hayati Bio-EXTRIM 4 kali menghasilkan biomassa kering daun dan diameter tengah umbi lebih tinggi dari pada frekuensi 5 dan 6 kali. Fenomena ini menunjukan frekuensi pemberian pupuk hayati Bio-EXTRIM yang tidak terlalu sering lebih optimal dibandingkan dengan frekuensi yang lebih sering diberikan. Diduga frekuensi 4 kali lebih cepat mendekomposisiskan pupuk kandang ayam yang memiliki kandungan $\mathrm{C} / \mathrm{N}$ rasio tinggi (29,19\%). Menurut Hanafiah (2013) pemanfatan bahan organik yang memiliki nisbah $\mathrm{C} / \mathrm{N}$ rasio di atas $20 \%$ akan menyebabkan kompetisi antara mikroba dengan mikroba dan mikroba dengan tanaman dalam penyerapan hara yang tersedia. Hal ini dipertegas oleh Fauzi (2008) bahwa bahan organik yang memiliki $\mathrm{C} / \mathrm{N}$ masih tinggi dapat merugikan tanaman apabila diberikan langsung pada media tanam, hal ini disebabkan karena senyawa anorganik menjadi senyawa organik berupa jaringan mikroba yang biasa disebut dengan immobilisasi. Selain itu, pengulangan pemberian pupuk hayati Bio-EXTRIM lebih sedikit menyebabkan penambahan Pseudomonas sp. lebih stabil dan tidak terjadi kompetisi. Menurut Sumarni, dkk. 
(2015) bahwa aplikasi bakteri Pseudomonas sp. berpengaruh positif terhadap berat kering tajuk dan akar tanaman tomat. Semakin besar berat kering tanaman berarti semakin baik pertumbuhan dan perkembangan tanaman. Menurut Anggun dkk. (2017) berat kering berangkasan tanaman menandakan kandungan fotosintat yang lebih banyak akibat dari proses fotosintesis yang berjalan dengan baik. Sementras itu, diameter umbi terbentuk dari akumulasi asimilat hasil fotosintesis yang disimpan dalam umbi. Keadaan ini menyebabkan umbi mengalami pembesaran ukuran dan peningkatan berat umbi sehingga berpengaruh terhadap diameter umbi (Anggun dkk, 2017).

Tabel 4. Biomassa Segar Umbi, Biomassa Segar Daun, Biomassa Segar Total Tanaman, Panjang Umbi, Tekstur Umbi, Kadar gula dan Perbandingan antara Korteks dan Stele Umbi pada Perlakuan Konsentrasi dan Frekuensi Pemberian Pupuk Hayati Bio-EXTRIM

\begin{tabular}{|c|c|c|c|c|c|c|c|c|}
\hline \multicolumn{2}{|c|}{ Perlakuan } & $\begin{array}{c}\text { BSU } \\
(\mathrm{g})\end{array}$ & $\begin{array}{l}\text { BSD } \\
(\mathrm{g})\end{array}$ & $\begin{array}{c}\text { BSTT } \\
(\mathrm{g})\end{array}$ & $\begin{array}{l}\mathrm{PU} \\
(\mathrm{cm})\end{array}$ & $\begin{array}{c}\mathrm{TU} \\
\left(\mathrm{kg} / \mathrm{cm}^{2}\right)\end{array}$ & $\begin{array}{c}\text { KG } \\
\left({ }^{\circ} \text { Brix }\right)\end{array}$ & $\mathrm{K} / \mathrm{S}$ \\
\hline \multicolumn{2}{|c|}{ k1 $(0,25 \%)$} & 56,00 & 44,73 & 100,73 & 11,96 & 3,20 & 12,37 & 2,07 \\
\hline \multicolumn{2}{|c|}{ k2 $(0,5 \%)$} & 40,93 & 30,2 & 71,13 & 10,89 & 3,65 & 12,59 & 2,44 \\
\hline \multicolumn{2}{|c|}{ k3 $(1 \%)$} & 41,47 & 35,00 & 76,47 & 10,7 & 3,25 & 11,81 & 2,51 \\
\hline \multicolumn{2}{|c|}{ BNJ 5\% } & - & - & - & - & - & - & - \\
\hline \multicolumn{2}{|c|}{ f1 (4 Kali) } & 56,93 & 44,87 & 101,8 & 12,01 & 3,28 & $12,48 a b^{*}$ & 2,00 \\
\hline \multicolumn{2}{|c|}{ f2 (5 Kali) } & 42,07 & 29,93 & 72,00 & 10,79 & 3,33 & $11,31 b^{*}$ & 2,62 \\
\hline \multicolumn{2}{|c|}{ f3 (6 Kali) } & 39,40 & 35,13 & 74,53 & 10,75 & 3,48 & $12,97 \mathrm{a}^{*}$ & 2,41 \\
\hline \multicolumn{2}{|c|}{ BNJ 5\% } & - & - & - & - & - & 1,44 & - \\
\hline \multirow[t]{3}{*}{$\mathrm{k} 1$} & f1 & 75,80 & 51,80 & 127,60 & 13,84 & 3,15 & 12,08 & 1,92 \\
\hline & $\mathrm{f} 2$ & 50,20 & 39,00 & 89,20 & 11,46 & 3,30 & 11,04 & 2.10 \\
\hline & $\mathrm{f} 3$ & 42,00 & 43,40 & 85,40 & 10,58 & 3,15 & 14,00 & 2,18 \\
\hline \multirow[t]{3}{*}{$\mathrm{k} 2$} & f1 & 43,40 & 33,60 & 77,00 & 11,38 & 3,90 & 12,80 & 1,89 \\
\hline & $\mathrm{f} 2$ & 41,00 & 27,80 & 68,80 & 10,88 & 3,35 & 12,00 & 3,23 \\
\hline & $\mathrm{f} 3$ & 38,40 & 29,20 & 67,60 & 10,40 & 3,70 & 12,96 & 2,2 \\
\hline \multirow[t]{3}{*}{$\mathrm{k} 3$} & f1 & 51,60 & 49,20 & 100,80 & 10,82 & 2,79 & 12,56 & 2,17 \\
\hline & $\mathrm{f} 2$ & 35,00 & 23,00 & 58,00 & 10,02 & 3,35 & 10,88 & 2,52 \\
\hline & f3 & 37,80 & 32,80 & 70,60 & 11,26 & 3,60 & 12,00 & 2,84 \\
\hline
\end{tabular}

BNJ $5 \%$

Keterangan: *Angka-angka dalam suatu kolom yang ditandai dengan huruf (superskrif) yang sama menunjukkan hasil yang berbeda nyata berdasarkan uji lanjut BNJ pada $\alpha=5 \%$, K: Konsentrasi, F: Frekuensi, BSU: Biomassa Segar Umbi, BSD: Biomassa Segar Daun, BSTT: Biomassa Segar Total Tanaman, PU: Panjang Umbi, TU: Tekstur Umbi, K:S Perbandingan antara korteks dan stele umbi.

Pada Tabel 4. menunjukan frekuensi pemberian pupuk hayati BioEXTRIM berpengaruh terhadap kadar gula umbi. Frekuensi pemberian pupuk hayati BioEXTRIM menghasilkan kadar gula umbi yaitu 11,31 - 12,97 ${ }^{\circ}$ Brix. Pupuk hayati Bio-EXTRIM selain 
mengandung mikroorganisme juga mengandung unsur hara kalium. Kalium merupakan unsur hara mako sekunder yang dibutuhkan oleh tanaman untuk proses translokasi gula hasil fotosintat keseluruh bagian tanaman atau ke tempat penyimpanan. Hal ini diperkuat dengan pernyataan (Alfian, dkk. 2019) yang menyatakan bahwa semakin tinggi dosis kalium maka semakin meningkatkan rasa manis yang berasrti kadar gula semakin tinggi.

Terdapat empat tingkat kadar gula untuk wortel yaitu: rendah $\left(<5^{\circ}\right.$ Brix.), sedang $(5-$ $9{ }^{\circ}$ Brix.), tinggi $\left(9-15{ }^{\circ}\right.$ Brix.) dan sangat tinggi ( $>15^{\circ}$ Brix) (Firmansyah, dkk, 2016). Berdasarkan hal tersebut, kadar gula umbi pada penelitian ini tergolong dalam kategori tingggi, dikarenakan rata-rata kadar gula pada perlakuan konsentrasi pemberian pupuk hayati BioEXTRIM adalah $11,81-12,59{ }^{\circ}$ Brix, sementra untuk perlakuan frekuensi pemberian pupuk hayati Bio-EXTRIM kadar gula rata-rata mencapai $11,31-12,97^{\circ}$ Brix . Pemberian pupuk hayati Bio-EXTRIM pada budidaya tanaman wortel varietas Gundaling dalam pot di dataran rendah menghasilkan umbi yang normal dengan berat 56,00 -56,93 g atau setara dengan 9,810 ton/ha, lebih rendah dari pada deskripsi tanaman wortel varietas Gundaling (Deskripsi Wortel Varietas Gundaling) yang memiliki potensi berat biomassa segar umbi yaitu 120 - 250 $\mathrm{g}$ atau setara dengan 25-30 ton/ha. Hal ini diduga dipengaruhi oleh lokasi penelitian yang berada di dataran rendah.

\section{KESIMPULAN}

Aplikasi pemberian pupuk hayati Bio-EXTRIM pada beberapa konsentrasi berpengaruh nyata terhadap laju pertambahan panjang tangkai daun dengan konsentrasi terbaik adalah 0,25\%. Frekuensi aplikasi pemberian pupuk hayati Bio-EXTRIM berpengaruh nyata terhadap biomassa kering daun, diameter tengah umbi dan kadar gula umbi, dengan aplikasi dengan frekuensi 4 kali menghasilkan biomassa kering daun dan diameter tengah umbi tertinggi sedangkan aplikasi sebanyak 6 kali menghasilkan umbi dengan kadar gula tertinggi. Akan tetapi, tidak terdapat interaksi antara konsentrasi dan frekuensi pemberian pupuk hayati BioEXTRIM dalam mempengaruhi pertumbuhan dan hasil tanaman wortel dalam pot yang ditanam di dataran rendah.

\section{Ucapan Terimakasih}

Peneliti mengucapkan terima kasih kepada Kementrian Riset, Teknologi dan Pendidikan Tinggi serta Universitas Mataram atas dana penelitian melalui skema Student Joint Reseach Tahun 2018 dan PNBP Tahun 2019.

\section{DAFTAR PUSTAKA}

Adelina R., Noorhamdani dan Mustafa A. 2013. Perebusan dan Penumisan Menurunkan Kandungan Beta Karoten dalam Wortel. Gizi dan Dietetik Indonesia 1 (3): 68 - 164.

Alfian M.S., Purnawati H. 2019. Dosis dan Waktu Aplikasi Pupuk Kalium pada Pertumbuhan dan Produksi Jagung Manis di BBPP Batangkaluku Kabupaten Gowa Sulawesi Selatan. Bulletin Agrohorti 7(1): 8-15. 
Anggun, Supriyono dan Syamsiyah J. 2017. Pengaruh Jarak Tanam dan Pupuk N, P, K terhdap Pertumbuhan dan Hasil Garut (Maranta arundinacea L.) Agrotech Research Journal $1(2): 33$ - 38.

Fatsecret Indonesia. 2018. Wortel. http://mobile.fatsecret.co.id/kalori-gizi/umum/wortel. [13 November 2018].

Fauzi A. 2008. Analisa Kadar Unsur Hara Karbon Organik dan Nitrogen di Dalam Tanah Perkebunan Kelapa Sawit Bengkalis Riau. [Tugas Akhir Diploma 3, Unpublished]. Universitas Sumatera Utara. Medan.

Firmansyah M. A., Liana T. dan Rahayu W. 2016. Uji Adaptasi Wortel di Tanah Lempung Liat Berpasir Dataran Rendah Palangka Raya. Journal of Horticulture 26 (2): 197-206.

Gunawan B. 2018. Biological Fertilizer Giving Effect on the Growth and Results of Two Plant Variety of Soybean (Glycine max L.). Jurnal Hasil Penelitian LPPM Universitas 17 Agustus 1945, Surabaya 03(01): 32-39

Hanafiah A.K. 2013. Dasar-Dasar Ilmu Tanah. PT. Rajagrafindo Persada. Palembang.

Kurniawan D. Kumalaningsih S., dan Sunyoto N.M.S., 2013. Pengaruh Volume Penambahan Effective Mikroorganisme 4 (EM4) 1\% dan Lama Fermentasi terhadap Kualitas Pupuk Bokashi dari Kotoran Kelinci dan Limbah Nangka. Jurnal Industria. 2 (1): 57-66.

Ningsih L.S. 2017. Dosis dan Kerapatan Pemberian Pupuk Bio-EXTRIM terhadap Pertumbuhan dan Hasil Tanaman Kol Bunga (Brassica oleracea). [Skripsi Sarjana, unpublished]. Fakultas Pertanian Universitas Mataram. Mataram.

Nikmatullah A., Hadi A.P., Hidayat S., Tamsil M.H., Suryatni M. Dan Sarjan M. 2018. Kajian Dampak Pemanfaatan Pekarangan dengan Pola KRPL. Laporan Peneitian. LSPB Mataram. Mataram.

Noviana I., B. Baharudin A. dan Sutriono, R. 2018. Pengaruh Konsentrasi BIO-EXTRIM ${ }^{\circledR}$ dan Dosis Pupuk Kandang Kambing Terhadap Pertumbuhan dan Hasil Tanaman Selada (Lactuca sativa L.). http://eprints.unram.ac.id. [03 Januari 2019].

Prijatna S. 2006. Penentuan Analisi Kimia Tanah. Fakultas pertanian Universitas Mataram. Mataram

Purwaningsih Y. 2008. Ketahanan Pangan: Situasi, Permasalahan, Kebijakan, dan Pemberdayaan Masyarakat. Jurnal Ekonomi Pembangunan. 9 (1): 1- 27.

Sagala A. D., Utami.S. dan Damanik A.S. 2011. Respon Pertumbuhan Bibit Kakao (Theobroma cacao L.) dengan Pemberian Pupuk Hayati Bio-EXTRIM pada Berbagai Media Tanam. Agrium, 17 (1): 7 - 11.

Saptana, Rusastra I.W., Susilowati, Situmorang J., Ashari, Purwantini B.T., Supriyatna Y., Nurasa T., Suharyono S. dan Ar-Rozi A.M. 2011. Laporan Akhir Penelitian T.A. 2011. Dampak Program Kawasan Rumah Pangan Lestari terhadap Kesejahteraan Rumah Tangga dan Pengembangan Ekonomi di Pedesaan. Pusat Analisis Sosial Ekonomi dan Kebijakan Pertanian. Badan Penelitian dan Pengembangan Pertanian. Kementerian Pertanian. 
Sumarni A., Aiyen dan Panggeso J. 2015. Pseudomonas Sp. Strain Dsmz 13134 dan Efektivitasnya pada Pertumbuhan Tanaman Tomat (Lycopersicum Esculentum Mill) serta Serapan P pada TanahMasam. Agrotekbis 3 (3): 338 - 344.

Wijayanti I.K.E., Widiarini I., dan Satriani R. 2017. Evaluasi Pelaksanaan Program Kawasan Rumah Pangan Lestari (KRPL) di Kelurahan Bobosan Kabupaten Banyumas. Prosiding Seminar Nasional Fakultas Pertanian UNS : 504 - 509.

Yonifwisma P. dan Tauran. 2016. Implementasi Program Kawasan Rumah Pangan Lestari (KRPL) bagi Rumah Tangga di Kelurahan Mojorejo Kecamatan Taman Kota Madiun. Publika 4 (8): $1-9$.

Zawani K., Nikmatullah A., Muslim K. dan Suryaningsih L. 2018. Pengembangan Wortel Baby Organik di Dataran Rendah. Prosiding PKM-CRS 1: $472-477$. 